\title{
KAJIAN SIFAT OPTIK FILM TIPIS BST DIDADAH NIOBIUM DAN TANTALUM
}

\author{
Farida Huriawati ${ }^{1}$ Irzaman $^{2}$ \\ ${ }^{1}$ Progam Studi Pendididkan Fisika FP MIPA \\ IKIP PGRI Madiun \\ Email: wicaknima@gmail.com \\ ${ }^{2}$ Departemen Fisika FMIPA \\ Intitut Pertanian Bogor \\ Email: wicaknima@gmail.com
}

\begin{abstract}
In this research thin films of Barium Strontium Titanate (BST) has been synthesis with different compositions $\mathrm{Ba}_{0,5} \mathrm{Sr}_{0,5} \mathrm{TiO}_{3}$ and $\mathrm{Ba}_{0,25} \mathrm{Sr}_{0,75} \mathrm{TiO}_{3}$ which doped by $\mathrm{Nb}_{2} \mathrm{O}_{5}$ (Niobium) and $\mathrm{Ta}_{2} \mathrm{O}_{5}$ (Tantalum) on Si (100) type-p substrate. Thin films were produced by chemical solution deposition technique (CSD) and spin coating technique with annealing temperature at $850^{\circ} \mathrm{C}$, $900^{\circ} \mathrm{C}$ dan $950^{\circ} \mathrm{C}$. Rotation velocity at $3000 \mathrm{rpm}$ and time of rotation is 30 seconds. Characterization of Films is optic Characterization (absorbance ana reflectance). From the Characterizations were obtained BNST thin film with 5\% doping and anneling temperature at $850^{\circ} \mathrm{C}$ as photodiode light sensor which applied in electronic circuit.
\end{abstract}

Keywords : Thin Film, $\mathrm{Ba}_{0,5} \mathrm{Sr}_{0,5} \mathrm{TiO}_{3}, \mathrm{Ba}_{0,25} \mathrm{Sr}_{0,75} \mathrm{TiO}_{3}$, doping, $\mathrm{Nb}_{2} \mathrm{O}_{5}$ (Niobium), $\mathrm{Ta}_{2} \mathrm{O}_{5}$ (Tantalum), Si (100) type-p substrate, Chemichal Solution Deposition (CSD), spin coating, annealing temperature, absobance, reflectance, light intensity.

\section{PENDAHULUAN}

Akhir-akhir ini, terdapat peningkatan penggunaan ferroelektrik material yang diaplikasikan dalam berbagai hal diantaranya : sensor dengan detektornya menggunakan sifat pizzoelektrik, multilayer kapasitor dengan memanfaatkan nilai konstanta dielektrik yang tinggi, infra red detector yang memanfaatkan prinsip piroelektrik (Saha, 2000). Beberapa jenis meterial ferroelektrik yang sering dipergunakan antara lain : Barium Strontium Titanate (BST), Lead Zirconium Titanate (PZT), Strontium Titanate (STO). Barium Strontium Titanate (BST) thin film telah lama dipelajari sebagai salah satu material yang dapat diaplikasikan untuk Non Volatile Memory Device, Dynamic Random Access Memory (DRAM), voltage tunable device, Infra Red (IR) dan sensor kelembaban. Karakteristik sifat kelistrikan dan material (mikrostruktur) dari lapisan tipis BST banyak dipengaruhi oleh metode pembuatan film, jenis material doping, suhu annealing, dan ukuran grain (Tae Gon, 2006). Dalam proses pembuatan BST thin film, ada beberapa metode yang dipergunakan diantaranya Pulsed Laser Deposition (PLD), Metal Organic Solution Deposition (MOSD), Sol-Gel Process (Tae Gon, 2006) dan RF Magnetron Sputtering. Metode Chemical Solution Deposition (CSD) telah lama dikembangkan untuk penumbuhan perovskite thin film semenjak tahun 1980-an dan dipublikasikan oleh Fukashima et al (Schwartz, 1997).

Dalam penelitian ini BST, BNST dan BSTT dibuat dengan metode chemical solution deposition (CSD) dan spin coating diatas substrat Si tipe-p. Dari film tipis BST, BNST dan BSTT yang telah dihasilkan akan dikarakterisasi, optik, dan kepekaan setiap film tipis sebagai sensor cahaya dilakukan dengan menggunakan multimeter. 


\section{TINJAUAN PUSTAKA}

Ferroelektrik adalah material yang memiliki polarisasi listrik akibat medan listrik eksternal, polarisasi ini dapat dihilangkan oleh medan listrik eksternal yang arahnya berlawanan. Film tipis Barium stronsium titanat (BST) memiliki konstanta dielektrik tinggi, kebocoran arus rendah dan tahan terhadap tegangan breakdown yang tinggi pada temperatur Curie. Temperatur Curie pada barium titanat adalah $130^{\circ} \mathrm{C}$ dengan adanya doping stronsium temperatur Curie menurun menjadi suhu kamar. Film tipis BST telah difabrikasi dengan beberapa teknik seperti sputtering, laser ablation, dan sol-gel process (N. V. Giridharan et al, 2005). Penambahan sedikit pendadah dapat menjadikan perubahan parameter kisi, konstanta dielektrik, sifat elektro-kimia, sifat elektro-optik dan sifat pyroelektrik dari keramik pada film tipis (A. C. W. Utami ,2007). Penambahan tantalum dan niobium akan mendapatkan bahan pyroelektrik bersifat menyerupai semikonduktor tipe- $n$ (donor doping).

\section{METODE PENELITIAN}

Bahan yang digunakan dalam penelitian ini adalah bubuk Barium Asetat $\left[\mathrm{Ba}\left(\mathrm{CH}_{3} \mathrm{COO}\right)_{2}, 99 \%\right]$, Stronsium Asetat [ $\left.\mathrm{Sr}\left(\mathrm{CH}_{3} \mathrm{COO}\right)_{2}, \quad 99 \%\right]$ Titanium Isopropoksida $\left[\mathrm{Ti}\left(\mathrm{C}_{12} \mathrm{O}_{4} \mathrm{H}_{28}\right), \quad 99.999 \%\right]$, Tantalum Pentoksida $\left[\left(\mathrm{Ta}_{2} \mathrm{O}_{5}\right)\right]$, Niobium Oksida $\left[\left(\mathrm{Nb}_{2} \mathrm{O}_{5}\right)\right]$, pelarut 2-metoksietanol [H3COCH2CH2OH, 99\%], substrat Si (100) tipe- $p$.

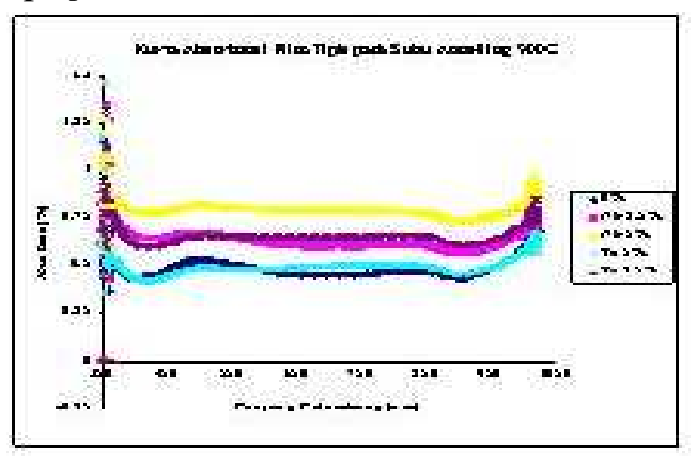

(a)
Penelitian ini terdiri dari dua tahap. Tahap pertama adalah proses sintesis film tipis BST, BNST dan BSTT menggunakan metode Chemical Solution Deposition (CSD) dan spin coating. Proses pada tahap pertama ini meliputi : persiapan Substrat $\mathrm{Si}$ Type- $p$, pembuatan larutan BST, BNST dan BSTT, proses penumbuhan film tipis, proses annealing, pembuatan kontak pada prototipe film tipis.

Tahap kedua adalah proses karakterisasi film tipis BST, BNST dan BSTT yang mencakup karakterisasi sifat optik (absorbansi dan reflektansi).

\section{HASIL DAN PEMBAHASAN \\ Karakterisasi Sifat Optik Film Tipis}

Pengukuran sifat optik film tipis ini menggunakan serat optik dengan metode refleksi dan suatu program Oceanoptic. Panjang gelombang yang digunakan dalam penelitian ini adalah panjang gelombang pada rentang panjang gelombang $339 \mathrm{~nm}$ sampai $1022 \mathrm{~nm}$. Rentang panjang gelombang tersebut mencakup cahaya ultraviolet visibel dan infrared (Douglas et al, 1998).

Dari kurva yang dihasilkan menunjukan bahwa daerah serapan dari film tipis mulai dari panjang gelombang $400 \mathrm{~nm}$ seterusnya atau pada rentang cahaya ultraviolet visibel sampai infrared. Hal tersebut menjelaskan bahwa film tipis dapat diaplikasikan juga sebagai sensor suhu. Dari hasil pengukuran diperoleh data persen absorbansi dan persen reflektansi.

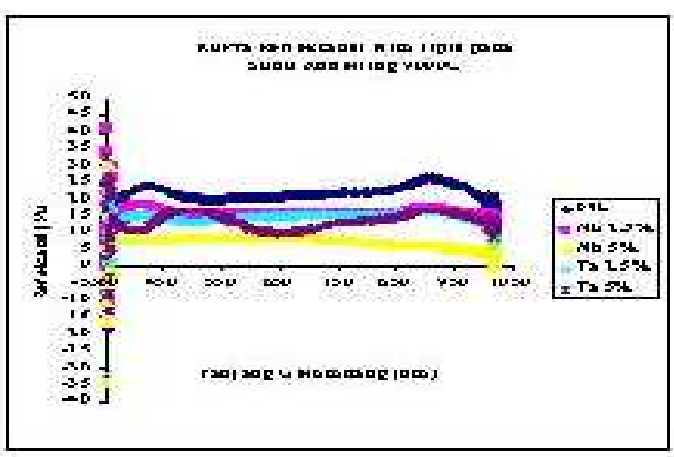

(b)

Gambar 1 (a) Kurva absorbansi film tipis pada suhu annelling $900^{\circ} \mathrm{C}$.

(b) Kurva reflektansi film tipis pada suhu annellling $9000 \mathrm{C}$. 
JPFK, Volume 1, Nomor 1, Maret 2015 : 9 - 13

Pada gambar 1(a) terlihat bahwa pada suhu anneling yang sama film tipis dengan jenis dan persentase pendadah yang berbeda memiliki persen absorbansi yang berbeda pula. Semakin besar persentase pendadah semakin besar pula nilai persen absorbansi dari film tipis. Sedangkan dari gambar 1(b) diperoleh juga persen reflektansi dengan analisis sebaliknya.Pada penelitian ini diperoleh bahwa film tipis dengan doping Niobium 5\% memliki persentase absorbsi terbesar dan selanjutnya film tipis dengan doping Tantalum 5\%, sedangkan film tipis tanpa doping memiliki persentase absorbsi

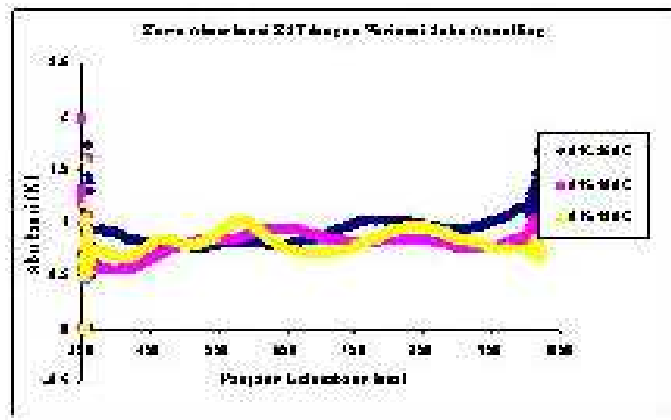

(a) paling kecil. Data sebaliknya dapat dilihat pada persentase refleksi film tipis. Berarti data absorbansi dan reflektansi saling mendukung, karena absorbsi adalah kebalikan dari reflektansi. Hal tersebut disebabkan oleh pengaruh persentase doping yang dapat menurunkan energi bandgap masing-masing film tipis yang diannealing pada $900^{\circ} \mathrm{C}$. Apabila atom donor ditambahkan pada suatu semikonduktor, tingkat energi yang diperkenankan akan berada sedikit di bawah pita konduksi (Cari, A. Supriyanto, 2004).

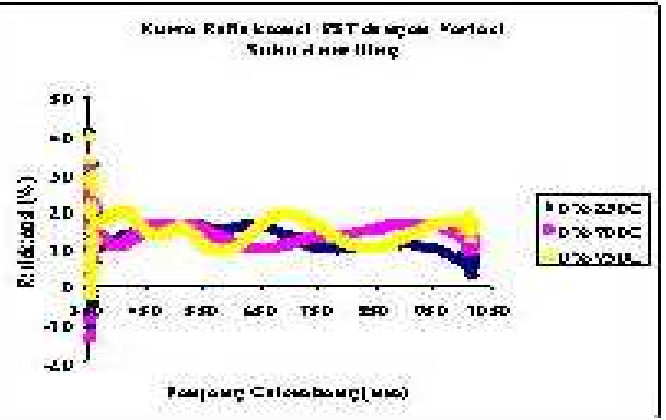

(b)

Gambar 2 (a) Kurva absorbansi BST dengan variasi suhu annelling $850^{\circ} \mathrm{C}, 900^{\circ} \mathrm{C}$, dan $950^{\circ} \mathrm{C}$.

(b) Kurva reflektansi BST dengan variasi suhu annelling $850^{\circ} \mathrm{C}, 900^{\circ} \mathrm{C}$, dan $950^{\circ} \mathrm{C}$.

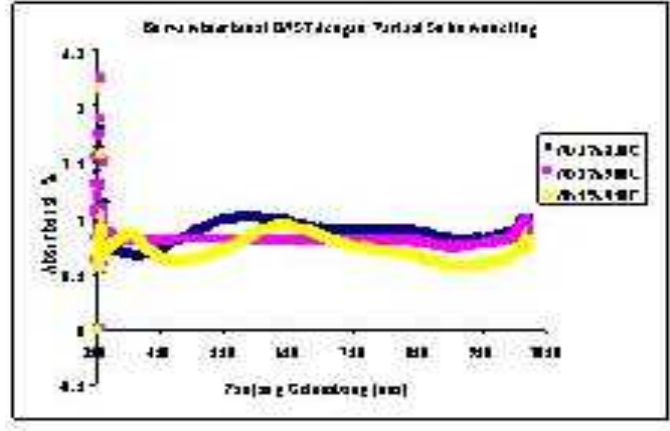

(a)

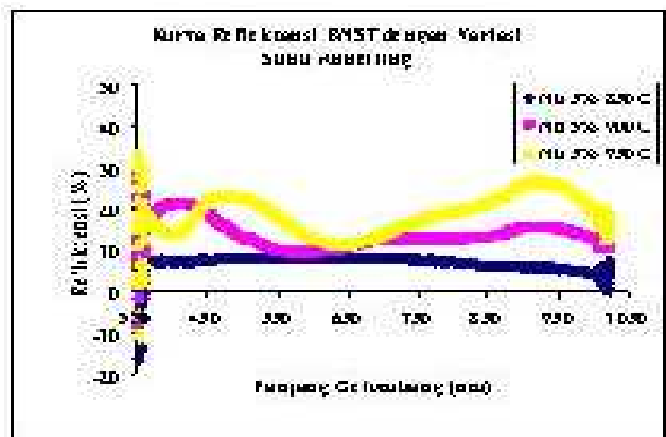

(b)

Gambar 3 (a) Kurva absorbansi BNST 5\% dengan variasi suhu annellling 8500C, 9000C, dan 9500C.

(b) Kurva reflektansi BNST 5\% dengan variasi suhu annellling 8500C, 9000C, dan 9500C 


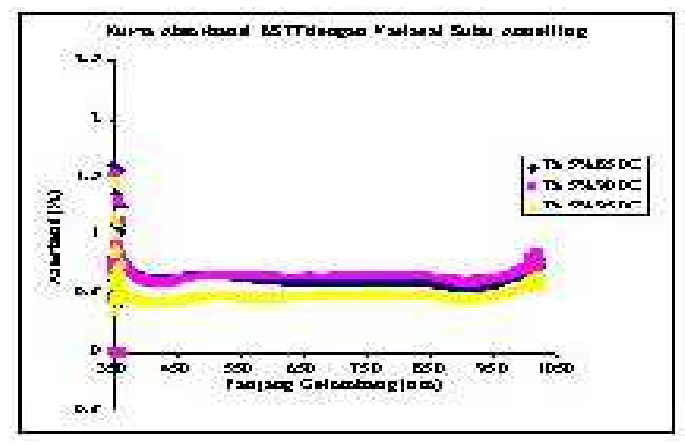

(a)

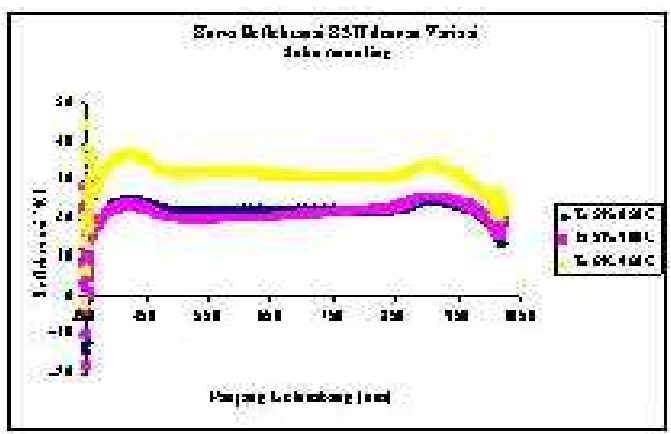

(b)

Gambar 4 (a) Kurva absorbansi BSTT 5\% dengan variasi suhu annellling 8500C, 9000C, dan 9500C.

(b) Kurva reflektansi BSTT 5\% dengan variasi suhu annelling 8500C, 9000C, dan 9500C.

Dari Gambar 2(a), 3(a), dan 4(a) terlihat bahwa dengan peningkatan suhu annelling pada persentase dan jenis doping yang sama mengakibatkan penurunan nilai persen absorbansi dari film tipis. Data sebaliknya dapat dilihat pada gambar 2(a), 3(a), dan 4(a) yang memberikan nilai persen reflektansi. Suhu annealing berpengaruh terhadap pembentukan kristal film tipis, sehingga strukturnya bisa berbeda. Struktur film tipis tersebut, berpengaruh terhadap sifat optik dari film tipis. Dari karakterisasi yang telah dilakukan, suhu annelling $850^{\circ} \mathrm{C}$ merupakan suhu annelling yang paling baik.

\section{KESIMPULAN}

Telah berhasil dilakukan sintesis film tipis BST, BNST dan BSTT menggunakan metode Chemical Solution Deposition (CSD) dan spin coating pada suhu anneling $850^{\circ} \mathrm{C}, 900^{\circ} \mathrm{C}$ dan $950^{\circ} \mathrm{C}$.

Kemerataan lapisan, proses penyolderan dan kekuatan kontak sangat mempengaruhi karakteristik film tipis. Variasi kombinasi kontak pada film yang sama memberikan karakteristik yang berbeda.

Penambahan doping pada film tipis BST memberikan karakteristik optik yang lebih baik pada film tipis tersebut. Dari karakterisari yang dilakukan, film tipis dengan suhu anneling $850^{\circ} \mathrm{C}$ memberikan karakteristik yang lebih baik dari pada film tipis dengan suhu anneling yang lain.

Dari hasil karaktersasi yang dilakukan diperoleh bahwa film tipis BNST 5\% dengan suhu annelling $850^{\circ} \mathrm{C}$ memberikan respon paling baik terhadap intensitas cahaya yang mengenainya, sehingga diaplikasikan sebagai sensor cahaya pada rangkaian elektronika saklar otomatis.

BST dan BST dengan penambahan doping dalam penelitian ini telah menunjukan sifat istimewanya yang peka terhadap cahaya atau sifat fotoelektrik, sehingga dapat diaplikasikan sebagai sensor cahaya fotodioda.

\section{DAFTAR RUJUKAN}

Azizahwati. 2002. Studi Morfologi Permukaan Film Tipis $\mathrm{PbZR}_{0,525} \mathrm{Ti}_{0,475} \mathrm{O}_{3} \quad$ yang Ditumbuhkan Dengan Metode DC Unbalanced Magnetron Sputtering. Jurnal Nasional Indonesia 5(1), Indonesia, hal 50-56

A. C. W. Utami. 2007. Studi Efek Fotovoltaik Film Tipis $\mathrm{Ba}_{0,5} \mathrm{Sr}_{0,5} \mathrm{TiO}_{3}$ yang Didadah Tantalum (BSTT) di Atas Substrat Si (100) Tipe-p. Skripsi, Departemen Fisika, Institut Pertanian Bogor

A. P. Malvino. 1990. Prinsip-prinsip Elektronika. Edisi ke-2 diterjemahkan oleh Hanapi Gunawan. Erlangga; Jakarta

Cari, A. Supriyanto, Suparmi,J.D. Malago, Irzaman, T.Sumardi, M.Hikam, I. Usman, A. Supu. 2004. Optical 
JPFK, Volume 1, Nomor 1, Maret 2015 : 9 - 13

Properties of Galium Oxide and Tantalum Oxide Doped $\mathrm{BaTiO}_{3}$ Thin Film. ProsidingPertemuan Ilmiah Ilmu Pengetahuan dan Teknologi Bahan 2004;

Serponghttp://www.national.com (national semiconductor. Oktober 2005)

H. Darmasetiawan.2005. Optimal Penumbuhan Film Tipis $\mathrm{BaTiO}_{3}$ yang didadah Indium dan Vanadium (BIVT) serta penerapannya sebagai Sel Surya. Institut Pertanian Bogor; Bogor

Irzaman, Y. Darvina, A. Fuad, P. Arifin, M. Budiman, and M. Barmawi. 2003. Physical and Pyroelectric Properties of Tantalum Oxide Doped Lead Zirconium Titanate [Pb0.9950(Zr0.525Ti0.465Ta0.010) O3] Thin Films and Its Application for IR Sensor. Physica Status Solidi (a), Germany, 199 (3), page 416 424.

J. A. Blackburn. 2001. Modern Instumentation for Scientists and Engineers. Spinger-Verlag; New York. Inc

K. Krane. 1992. Fisika Modern. Penerjemah Hans J. Universitas Indonesia. Depok

P.A. Tippler.1991. Physic for Scientist and Engineers. Worth Publisher. Inc

M. A. Omar.1993. Elementary Solid State Physics. Addison-Wesley Publishing Company, Inc

N. V. Giridharan, R. Jayavel, P. Ramasamy. 2001. Structural, Morphological and Electrical Studies on Barium Strontium Titanate Thin Films Prepared by Sol-Gel Technique. Crystal Growth Centre, Anna
University, Chennai, India, 36, 6572

R. E. Smallman.1991. Metalurgi Fisik Modern (Edisi ke-4). Gramedia Pustaka Utama; Jakarta

S. Amiruddin, Usman,Mursal, T.Winata, dan Sukirno. 2005. OptimasiParameter Tekanan Deposisi pada Penumbuhan Lapisan Tipis Polykristal Silikon dengan Metode Hot Wire Cell PECVD. Jurnal Matematika da Sains Vol 10 No. 1 hal 27-30

Saha Sanjib, 2000 "Study of pulsed laser ablated Barium Strontium Titanate Thin films for dynamic Random Access Memory Application", Thesis, Material Research Centre, Indian Institute of Science, Bangalore India, August 2000.

Schwartz, Robert W, 1997 "Chemical Solution Deposition of Perovskite Thin Film", Chem. Mater, 23252340.

Sutrisno. 1986.Elektronika Teori dan Penerapannya. ITB; Bandung

Tae Gon Ha, 2006 "Cu-Doping Effect on the Dielectric and Insulation Properties of Sol-Gel Derived $\mathrm{Ba}_{0.7} \mathrm{Sr}_{0.3} \mathrm{TiO}_{3}$ Thin Film", Journal of Korean Physical Society, Vol 49, December 2006, pp.S571ᄀS574

$\mathrm{Wu}$, N. J, Y. S. Chen, S. Dorderic, A. Ignatiev. 1997. Pyroelectric IR Sensor Based on Oxide Heterostructures on Si (100) and LaAlO3 (100) Substrates. Proceeding Third International Conference on Thin Film Physics and Applicatio. SPIE Vol. 3175, hal 256-261 